\title{
Effect of Different Salinity Level on Tomato (Lycopersicon esculentum) Production under Climate Change Condition in Bangladesh
}

\author{
Nizam Uddin Ahmed ${ }^{1}$, Nashir Uddin Mahmud ${ }^{2}$, Md. Asad Uz Zaman ${ }^{3}$, \\ Zannatul Ferdous ${ }^{4^{*}}$ and Shyam Chandra Halder ${ }^{1}$ \\ ${ }^{1}$ Tuber Crops Research Sub-station, Bangladesh Agricultural Research Institute, Munshiganj, \\ ${ }^{2}$ Soil Science Division, Bangladesh Agricultural Research Institute, Regional Agriculturalesh. \\ ${ }^{2}$ Soil Science Division, Bangladesh Agricultural Research Institute, Regional Agricultural Research \\ Station, Jessore, Bangladesh. \\ ${ }^{3}$ Rice Farming Systems Division, Bangladesh Rice Research Institute, Gazipur, Bangladesh. \\ ${ }^{4}$ On-Farm Research Division, Bangladesh Agricultural Research Institute, Agricultural Research
} Station, Alamnagar, Rangpur, Bangladesh.

\section{Authors' contributions}

This work was carried out in collaboration between all authors. Author NUA designed the study, performed the statistical analysis, wrote the protocol and wrote the first draft of the manuscript. Authors NUM and MAUZ managed the analyses of the study. Authors ZF and SCH managed the literature searches, edited and improved the manuscript. All authors read and approved the final

manuscript.

Article Information

DOI: $10.9734 / A R R B / 2017 / 33613$ Editor(s):

(1) Jin-Zhi Zhang, Key Laboratory of Horticultural Plant Biology (Ministry of Education), College of Horticulture and Forestry Science, Huazhong Agricultural University, China.

(2) David L. Herrin, Molecular Cell \& Developmental Biology, The University of Texas at Austin, USA.

(3) George Perry, Dean and Professor of Biology, University of Texas at San Antonio, USA

(1) Fernando Ferrari Putti, School of Science and Engineering, UNESP - São Paulo State University, Brazil.

(2) S. Metin Sezen, Çukurova University, Adana, Turkey.

Complete Peer review History: http://www.sciencedomain.org/review-history/19391

Original Research Article

Received $23^{\text {rd }}$ April 2017

Accepted $23^{\text {rd }}$ May 2017

Published $7^{\text {th }}$ June 2017

\begin{abstract}
Tomato is a crop with the greatest economic importance in the world and salinity stress causes are reduction in the quantity and quality of crop production. Today the main challenge in world agriculture is to sustain the continuously growing global population, and this becomes more difficult due to climatic change, as this imposes further abiotic stress. The aim of this study was to find out
\end{abstract}


the salinity effect on tomato production. The study was initiated at the Irrigation and Water Management (IWM) research field of Bangladesh Agricultural University (BAU), Bangladesh during October 2007 to April 2008 cropping season. The experiment was carried out in a randomized complete block design (RCBD) with 3 replications. The treatments were: $T_{1}=$ Irrigation with fresh

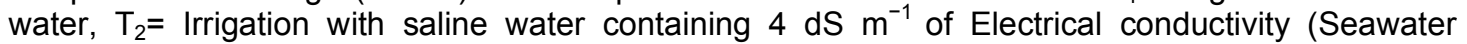
cannot hold as much dissolved oxygen as freshwater due to its high salinity. Conductivity and salinity have a strong correlation.), $\mathrm{T}_{3}=$ Irrigation with saline water containing $6 \mathrm{dS} \mathrm{m}^{-1}$ of Electrical conductivity, $\mathrm{T}_{4}=$ Irrigation with saline water containing $8 \mathrm{dS} \mathrm{m}^{-1}$ of Electrical conductivity and $\mathrm{T}_{5}=$ Irrigation with saline water containing $10 \mathrm{dS} \mathrm{m}^{-1}$ of Electrical conductivity. We found that the plants irrigated with the $T_{1}$ treatment (Irrigation with fresh water) was the highest fruit yield plant ${ }^{-1}(1.52 \mathrm{~kg})$ whereas the lowest yield $(0.667 \mathrm{~kg})$ was obtained from the higher level of saline water treatment $T_{5}$ $\left(10 \mathrm{dS} \mathrm{m}^{-1}\right)$. When the fruit yield was considered the effective treatment for the highest total fruit yield $\left(36.57 \mathrm{t} \mathrm{ha}^{-1}\right)$ was produced by the $\mathrm{T}_{1}$ treatment (Irrigation with fresh water) and the lowest fruit

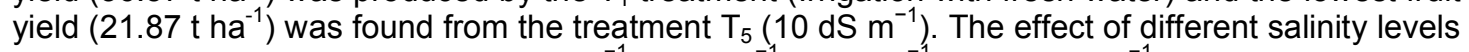
of irrigation such as fresh water, $4 \mathrm{dS} \mathrm{m}^{-1}, 6 \mathrm{dS} \mathrm{m}^{-1}, 8 \mathrm{dS} \mathrm{m}^{-1}$ and $10 \mathrm{dS} \mathrm{m}^{-1}$ on total soluble solid was significantly influenced. The highest total soluble solid (2.53) was shown in $T_{5}$ treatment (10 dS $\mathrm{m}^{-1}$ ) whereas the lowest (2.00) in Irrigation with fresh water treatment.

Keywords: Saltiness; vegetables; environmental change; Bangladesh/developing countries like Bangladesh.

\section{INTRODUCTION}

Tomato (Lycopersicon esculentum) belonging to the family Solanaceae, is one of the most important, popular, nutritious and palatable vegetables grown in Bangladesh. It plays a vital role in providing a remarkable quantity of vitamin$A$ and vitamin- $C$ in human diet. It can be eaten both in raw as well as ripe and after cooking. Tomato is cultivated all over Bangladesh due to its adaptability to wide range of soil and climate.

In Bangladesh, tomato has a great demand throughout the year, but its production is mainly concentrated during the winter season. Recent statistics show that tomato was grown in 26757 hectares of land and total production was approximately 359935 metric tons in 2013-2014. Thus the average yield of tomato was 13.45 metric tons ha-1 [1], while it was $69.41 \mathrm{t} \mathrm{ha}^{-1}$ in USA and $59.26 \mathrm{t} \mathrm{ha}^{-1}$ in Japan [2]. The low yield of tomato in Bangladesh, however, is not an indication of low yield potentiality of this crop, but the low yield may be attributed to a number of reasons, such as lack of hybrid/improved varieties, unavailability of quality seeds of hybrid/improved varieties and sub- optional management practices [3]. One of the major problems confronting irrigated agriculture nowadays throughout the world is the decreasing availability of fresh water. In many countries and regions, fresh water is relatively scarce, but there are considerable resources of saline water, which could be utilized for irrigation if proper crops, soil and water management practices were established [4,5]. In Bangladesh, especially in south Bangladesh plain, fresh irrigation water is becoming less and less with time.

Bangladesh is primarily an agriculture-based economy and agriculture is the leading source of employment, income, and food and nutrition security [6]. Over thirty percent of the net cultivable area exists in the coastal regions of Bangladesh. Out of 2.85 million hectares of the coastal and offshore areas, about 0.833 million hectares of the arable lands, which constitutes $52.8 \%$ of net cultivable saline area are dispersed in 64 subdistricts of 13 districts. In those areas, the ranges of the salinity are categorized on the basis of electrical conductivity (EC) between 2 $\mathrm{dS} \mathrm{m}^{-1}$ and $16 \mathrm{ds} \mathrm{m}^{-1}$. The severity of salinity problem in Bangladesh increases from November to May with the desiccation of the soil when concentration of salts in the soil surface builds up by rapid evapotranspiration (ET). During the wet monsoon, the severity of salt injury is reduced due to dilution of the salt in the root-zone of the standing crop.

Under conditions of high soil salinity, many crop plants, including tomato, are susceptible and cannot survive or can survive only with decreased yields. To alleviate the deleterious effects of salinity, the measures such as the reclamation of salinized lands, the improvement of irrigation with saline water and the cultivation of salt-tolerant variety have been applied [7]. As observed and considered in the context of the above factors, salt stress is applied to improve 
fruit quality, but little is known about the interaction between the organoleptic composition of tomato fruit and salt stress [8]. The positive changes in tomato quality have been obtained under certain salinity treatments. However, the tomato yield has been reported to be negatively affected by the increasing salinity [9].

The safe and efficient use of saline water for irrigation is to undertake appropriate practices to prevent the development of excessive soil salination for crop production. Many factors should be considered in making management strategies, such as crop cultivars, local climate, soil nutrients, type of salt, salinity levels, irrigation method and water management practices $[10,11]$. Minhas [12] indicated that applying nonsaline water in sensitive stage and saline water in relatively tolerant stage could minimize the reduction in yield by salinity. They pointed out that evapotranspiration of tomato decreased moderately with the increase of salinity, whereas the fruit yield decreased strongly. Del Amor et al. [13] conducted a greenhouse study where tomatoes (cutivar- Daniela) were drip irrigated with nutrient solutions of four salinity levels $(2,4$, 6 and $8 \mathrm{dS} \mathrm{m}^{-1}$ ) at three different plant growth stages. They found that salt tolerance of tomato plants increased when the application of salinity was delayed, and fruit quality improved while yield was not significantly reduced when 4 dS $\mathrm{m}^{-1}$ saline water was applied 16 days after transplanting. Tomatoes responses to salinity in laboratory or greenhouse have been well summarized by Cuartero et al. [14].

Soil salinity has a detrimental effect on the soil chemical and physical properties, and this hinders plant growth and production [15-16] in a measure that depends on the salt tolerance of each crop. Soluble salts lower the osmotic potential of the soil water, thus lower leaf water potential is required to sustain transpiration [17]. In other words, plants spend more energy making osmotic adjustments [16]. Due to very slow infiltration and percolation rates, plants grown in saline soils often show symptoms of water deficit, especially under conditions of high evaporative demand [4]. Elevated salt and $\mathrm{Na}^{+}$ concentrations in soils may be highly toxic to many plants, although tolerance levels vary among different species. High levels of $\mathrm{Na}^{+}$can cause imbalance in the uptake and utilization of other cations and disruption of chloroplasts, which results in reduced photosynthesis [4]. For this reason the most sensitive plants may suffer physiological damages, with subsequent, significant yield loss, while moderately sensitive to tolerant plants are still able to produce acceptable yields [18].

Due to the decreasing availability of fresh water to agriculture in many regions, saline water utilization in irrigation gets more and more attention in order to facilitate the safe use of saline water for irrigation, the effects of salinity and frequent fertigation on crops should be understood, and optimal management strategies need to be developed. Considering the above facts, to evaluate the effect of different salinity levels of irrigation water on the growth and yield of tomato, and to compare the growth and yield of tomato with saline water and fresh water irrigation.

\section{MATERIALS AND METHODS}

\subsection{Site Description and Experimental Design}

The experiment was conducted from 25 December, 2007 to 03 April, 2008. The study was initiated at the Irrigation and Water Management (IWM) research field of Bangladesh Agricultural University (BAU), Bangladesh during October 2007 to April 2008 cropping season to find out the salinity effect on tomato production. The experiment was carried out in a randomized complete block design (RCBD) with 3 replications. The unit plot size was $8 \mathrm{~m} \times 5 \mathrm{~m}$. The treatments were: $T_{1}=$ Irrigation with fresh water, $\mathrm{T}_{2}=$ Irrigation with saline water containing $4 \mathrm{dS} \mathrm{m}^{-1}$ of Electrical conductivity, $\mathrm{T}_{3}=$ Irrigation with saline water containing $6 \mathrm{dS} \mathrm{m}^{-1}$ of Electrical conductivity, $\mathrm{T}_{4}=$ Irrigation with saline water containing $8 \mathrm{dS} \mathrm{m}^{-1}$ of Electrical conductivity and $\mathrm{T}_{5}=$ Irrigation with saline water containing $10 \mathrm{dS}$ $\mathrm{m}^{-1}$ of Electrical conductivity. The study area is located at $24^{\circ} 75^{\prime} \mathrm{N}$ latitude and $90^{\circ} 50^{\prime} \mathrm{E}$ longitude and $19 \mathrm{~m}$ above the mean sea level (MSL). The soil of the experimental area was silt loam underlain by sandy loam and belongs to the Old Brahmaputra Floodplain [19]. The physical properties of different soil layers of the experimental field are given in Table 1. The organic matter content of the experimental soil was low. Top soils are moderately acidic but sub soils are neutral in reaction. The field capacity and permanent wilting point of the soil of the experimental field are 38.19 and $18.37 \%(\mathrm{v} / \mathrm{v})$, respectively and the bulk density $1.33 \mathrm{~g} \mathrm{~cm}^{-3}$. The physio-chemical properties of initial soil samples of the experimental field are given in Table 2 . The climate is sub-tropical with an average rainfall of $2420 \mathrm{~mm}$ concentrated over the month 
Table 1. Soil physical properties of different soil layers of the experimental field

\begin{tabular}{|c|c|c|c|c|c|c|c|}
\hline \multirow{2}{*}{$\begin{array}{l}\text { Soil } \\
\text { depth } \\
\text { (cm) }\end{array}$} & \multicolumn{3}{|c|}{$\begin{array}{l}\text { Particle size distribution } \\
(\%)\end{array}$} & \multirow{2}{*}{$\begin{array}{l}\text { Bulk } \\
\text { density } \\
\left(\mathrm{g} \mathrm{cm}^{-3}\right)\end{array}$} & \multirow[t]{2}{*}{$\begin{array}{l}\text { Textural } \\
\text { class }\end{array}$} & \multirow[t]{2}{*}{$\begin{array}{l}\text { Field } \\
\text { capacity (\%) }\end{array}$} & \multirow{2}{*}{$\begin{array}{l}\text { Wilting } \\
\text { point } \\
(\%)\end{array}$} \\
\hline & Sand & Silt & Clay & & & & \\
\hline $0-20$ & 32.57 & 56.66 & 10.76 & 1.26 & Silt loam & 39.10 & 18.61 \\
\hline $20-40$ & 54.57 & 40.0 & 5.43 & 1.35 & Sandyloam & 38.62 & 18.35 \\
\hline $40-60$ & 67.91 & 26.67 & 5.42 & 1.40 & Sandyloam & 36.85 & 18.16 \\
\hline
\end{tabular}

Table 2. Soil chemical properties of different soil layers of the experimental fields before transplanting

\begin{tabular}{llll}
\hline Parameters & \multicolumn{3}{c}{ Soil depth } \\
\cline { 2 - 4 } & $\mathbf{0 - 2 0} \mathbf{~ c m}$ & $\mathbf{2 0 - 4 0} \mathbf{~ c m}$ & $\mathbf{4 0 - 6 0} \mathbf{~ c m}$ \\
\hline $\mathrm{pH}(1: 2.5$ soil:water) & 6.75 & 7.00 & 6.96 \\
Electrical conductivity $(\mathrm{mS} / \mathrm{cm})$ & 102.3 & 45.66 & 37.33 \\
Organic carbon $(\%)$ & 0.8353 & 0.3406 & 0.278 \\
Total nitrogen $(\%)$ & 0.0716 & 0.029 & 0.0233 \\
Available phosphorus $(\mathrm{ppm})$ & 17.96 & 17.50 & 16.21 \\
Exchangeable potassium $(\mathrm{ppm})$ & 26.85 & 24.17 & 25.51 \\
Available Sulphur $(\mathrm{ppm})$ & 12.72 & 7.87 & 9.05 \\
Exchangeable sodium $(\mathrm{ppm})$ & 9.41 & 7.06 & 8.73 \\
Exchangeable calcium $(\mathrm{ppm})$ & 741.82 & 803.91 & 526.14 \\
\hline
\end{tabular}

of May to September. The summer is hot and humid and the winter (November-February) is moderate with intermittent rainfall. The maximum temperature during the warm month of April to May varies from $28.8^{\circ} \mathrm{C}$ to $35.9^{\circ} \mathrm{C}$ while January is the coldest month. The minimum temperature varies from $9.6^{\circ} \mathrm{C}$ to $12.9^{\circ} \mathrm{C}$.

\subsection{Crop Management}

The source of N, P, K, S and B was urea, triple super phosphate, murate of potash, gypsum and boric acid, respectively. The crop was planted on 3-6 December in 2007 and maintaining $60 \mathrm{~cm} \times$ $40 \mathrm{~cm}$ plant spacing. Weeding was done as and when necessary to keep the crop free from weeds. There were three irrigation applied by furrow method like 25-30 DAT (Days after transplanting), 45-50 DAT and 60-65 DAT. As preventive measure against insect pests, Dimeron was applied at the rate of $2 \mathrm{ml} \mathrm{L}^{-1}$ water. The insecticide was applied at 10 days interval from a week after transplanting to a week before first harvesting. Furadan 5G was also applied during the final land preparation as soil insecticide. During foggy weather, precautionary measures against disease infestation, especially late blight of tomato, was taken by fortnightly spraying of Admire at the rate of $2 \mathrm{ml} \mathrm{L}^{-1}$ water. Fruits were harvested at 2 to 3 days interval during early ripe stage when they attained slightly red colour. The harvesting was started from 20 March and completed by 30 April, 2008.

\subsection{Data Collection and Statistical Analysis}

After maturing randomly 5 plants were harvested to record the yield and yield contributing characters of tomato. Fruit yield was harvested from randomly pre-selected central areas (about $9 \mathrm{~m}^{-2}$ ) of each plot and converted into tons per hectare $\left(\mathrm{t} \mathrm{ha}^{-1}\right)$. Mean data was analyzed statistically and was carried out to analysis of variance (ANOVA) using the MSTAT-C.

\section{RESULTS AND DISCUSSION}

Yield and yield contributing characters of tomato for different treatments are shown in Table 3.

\subsection{Effect of Different Irrigation Treat- ments on Plant Height and Number of Branch of Tomato}

The plant height was measured at maximum vegetative growth stage (85 DAT). Different levels of saline water irrigation such as fresh water, $4 \mathrm{dS} \mathrm{m}^{-1}, 6 \mathrm{dS} \mathrm{m}^{-1}, 8 \mathrm{dS} \mathrm{m}^{-1}$ and $10 \mathrm{dS}$ $\mathrm{m}^{-1}$ had significant influence on plant height (Table 3). Plant height decreased gradually with the advancement of time in all the treatments. The plant height decreased with the increasing 
doses of salinity level. The maximum plant height $(82.67 \mathrm{~cm})$ was recorded from the $T_{1}$ treatment (Fresh water) and the minimum plant height $(66 \mathrm{~cm})$ was recorded from the highest level of salinity of treatment $T_{5}$ $\left(10 \mathrm{dS} \mathrm{m}^{-1}\right.$ ) (Table 3). Decreased plant height with the increasing salinity level was possibly due to soil chemical and physical properties, and this hinders plant growth and production in a measure that depends on the salt tolerance of each crop $[5,16]$. Soluble salts lower the osmotic potential of the soil water, thus a lower leaf water potential is required to sustain transpiration [16]. In other words, plants spend more energy making osmotic adjustments [16].

\subsection{Number of Branch per Plant}

The impact of different salinity level on the number of branch is shown in Table 3. For all the treatments it was observed that the number of branch per plant decreased significantly with the advancement of time. Control water salinity (Fresh water) was found to be the highest in number of branch whereas the lowest was found in $\mathrm{T}_{5}\left(10 \mathrm{dS} \mathrm{\textrm {m } ^ { - 1 } )}\right.$ treatment.

\subsection{Number of Mature Fruits per Plant}

Analysis of variance showed that the different levels of saline water irrigation such as fresh

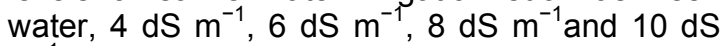
$\mathrm{m}^{-1}$ had significant influence on the number of mature fruits per plant (Table 3 ). The number of mature fruits per plant ranged from 14.33 to 31.59. Results revealed that the highest number of mature fruits per plant was produced by the $T_{1}$ treatment (Irrigation with fresh water) and then decreased gradually.

\subsection{Fruit Length}

The length of individual fruit was significantly influenced by different levels of water salinity such as fresh water, $4 \mathrm{dS} \mathrm{m}^{-1}, 6 \mathrm{dS} \mathrm{m}^{-1}, 8 \mathrm{dS}$ $\mathrm{m}^{-1}$ and $10 \mathrm{dS} \mathrm{m} \mathrm{m}^{-1}$ (Table 3 ). The largest length value $(4.97 \mathrm{~cm})$ and the shortest length value $(3.91 \mathrm{~cm})$ of individual fruit were observed from the $T_{1}$ treatment (Fresh water) and the $T_{5}$ treatment $\left(10 \mathrm{dS} \mathrm{m}^{-1}\right.$ ), respectively (Table 3 ). It is noticed that the plants irrigated with fresh water gave the tallest fruit $(4.97 \mathrm{~cm})$ followed by $\mathrm{T}_{1}$ treatment (Fresh water) whereas the shortest fruit $(3.91 \mathrm{~cm})$ followed by $T_{5}$ treatment (10dS $\left.\mathrm{m}^{-1}\right)$.

\subsection{Fruit Diameter}

The different levels of water salinity for irrigation of tomato significantly influenced the diameter of individual fruit (Table 3$)$. The largest $(5.82 \mathrm{~cm})$ and shortest $(4.62 \mathrm{~cm})$ diameters of individual fruit were measured from the $\mathrm{T}_{1}$ treatment (Fresh water) and the higher level of salinity treatment $\mathrm{T}_{5}\left(10 \mathrm{dS} \mathrm{m}^{-1}\right.$ ) (Table 3 ). This may be due to the fact that the presences of the $\mathrm{NaCl}$ in the field in an unsuitable combination retard the vegetative growth of the plants. The higher level of salinity resulted in minimum height of plant $(66 \mathrm{~cm})$ with minimum number of leaves that might have decreased the photosynthetic activities and prepared sufficient food for the plant growth and fruit enlargement. High levels of $\mathrm{Na}^{+}$can cause imbalance in the uptake and utilization of other cations and disruption of chloroplasts, which results in reduced photosynthesis [20].

\subsection{Weight of Individual Fruit}

The variation in individual fruit weight due to the application of different levels of water salinity such as fresh water, $4 \mathrm{dS} \mathrm{m}^{-1}, 6 \mathrm{dS} \mathrm{m} \mathrm{m}^{-1}, 8 \mathrm{dS}$ $\mathrm{m}^{-1}$ and $10 \mathrm{dS} \mathrm{m}^{-1}$ was significantly influenced (Table 3). The maximum individual fruit weight $(65.44 \mathrm{~g})$ was received from the $T_{1}$ treatment (Fresh water) whereas the lowest individual fruit weight $(46.55 \mathrm{~g})$ was recorded from the higher level of saline water treatment $\mathrm{T}_{5}$ (Table 3 ). Higher level of saline water in $\mathrm{T}_{5}$ treatment provided the plants insufficient foods with decreased cell division, which contributed to the minimum fruit weight. In addition, this result may be due to the fact that the presence of higher level of salinity in an unsuitable combination retard the vegetative growth of the plants but it was also possibly due to less stored food materials present in the fruit resulting in smaller size. Brady and Weil [16] reported that when a soil contains relatively high levels of sodium on the exchange complex to interfere with the growth of most crop plants it becomes sodic.

The different levels of saline water irrigation such as fresh water, $4 \mathrm{dS} \mathrm{m}^{-1}, 6 \mathrm{dS} \mathrm{m}^{-1}, 8 \mathrm{dS} \mathrm{m}^{-1}$ and $10 \mathrm{dS} \mathrm{m}^{-1}$ had also significant effect on fresh weight of fruit per plant (Table 3 ). The maximum weight of fruits per plant $(1.52 \mathrm{~kg})$ was recorded from the $T_{1}$ treatment (Irrigation with fresh water) and the lowest weight of fruits was recorded from the irrigation with higher level of salinity of treatment $\mathrm{T}_{5}\left(10 \mathrm{dS} \mathrm{m}^{-1}\right)$ (Table 3$)$. The minimum fruit weight plant ${ }^{-1}$ might be due to imbalanced irrigation with saline water because normal 
metabolic processes can continue only in the presence of an optimum level of saline water. Application of optimum level of salinity plays a significant role in the promotion of number of fruits as well as weight of fruits plant ${ }^{-1}$.

\subsection{Fruit Yield}

The maximum fruit yield $\left(36.57 \mathrm{t} \mathrm{ha}^{-1}\right)$ was produced by the plants grown under the $T_{1}$ treatment (Irrigation with fresh water) whereas the lowest fruit yield $\left(21.87 \mathrm{t} \mathrm{ha}^{-1}\right)$ was found from the higher level of saline water treatment $T_{5}$ $\left(10 \mathrm{dS} \mathrm{m}^{-1}\right)$. Elamin \& Al-Wehaibi [21] observed that the most sensitive plants may suffer physiological damages, with subsequent, significant yield loss, while moderately sensitive to tolerant plants are still able to produce acceptable yields.

\subsection{Yield Decrease over Control}

In Table 3, different levels of saline water irrigation such as fresh water, $4 \mathrm{dS} \mathrm{m}^{-1}, 6 \mathrm{dS}$ $\mathrm{m}^{-1}, 8 \mathrm{dS} \mathrm{m}^{-1}$ and $10 \mathrm{dS} \mathrm{m}^{-1}$ had also shown significant difference on yield decrease over the control treatment. The highest level of yield decrease over control occurred in the highest level of saline water treatment $T_{5}$. In fact, the yield of crop decreased gradually with the increased of saline water level.

\subsection{Total Soluble Solids}

The analysis of variance given in Fig. 1 revealed that the effect of different salinity levels of irrigation such as fresh water, $4 \mathrm{dS} \mathrm{m}^{-1}, 6 \mathrm{dS}$ $\mathrm{m}^{-1}, 8 \mathrm{dS} \mathrm{m}^{-1}$ and $10 \mathrm{dS} \mathrm{m}^{-1}$ on total soluble solid was significantly influenced (Fig. 1). The highest value of total soluble solid had shown in the higher level of saline water treatment $T_{5}(10$ $\mathrm{dS} \mathrm{m}^{-1}$ ) whereas the lowest value of total soluble solid had found from the control (Irrigation with fresh water) (Fig. 1). In general, increase in water salinity has increased the value of total soluble solid whereas the moisture content decreases gradually. Leone et al. [17] reported that irrigation with saline water slightly reduced fruit water content. Under the high-saline water irrigation $(5.5 \mathrm{dS} / \mathrm{m})$ treatment, the fruit soluble solids, total acid, vitamin $\mathrm{C}$ and sugar-acid ratio increased [5]. A positive relationship between the tomato comprehensive quality and salinity of irrigation water was found in the experiment.

\subsection{Water Requirement and Field Water Use Efficiency}

In Table 4, total water used based on water requirement and water use efficiency based on the yield $\left(\mathrm{kg} \mathrm{ha}^{-1}\right)$ per water application $(\mathrm{mm})$ has been calculated under different level of water salinity. Total water application for all the treatments was same and it was $1.72 \mathrm{~mm}$ as per the experimental specifications. The values of water use efficiency for tomato yield were $212.00,202.1,175.47,161.33$ and $126.78 \mathrm{~kg} \mathrm{ha}^{-}$ ${ }^{1} \mathrm{~mm}^{-1}$ for treatments $\mathrm{T}_{1}, \mathrm{~T}_{2}, \mathrm{~T}_{3}, \mathrm{~T}_{4}$ and $\mathrm{T}_{5}$, respectively. The highest water use efficiency (2120.00 kg ha $\mathrm{mm}^{-1}$ ) was obtained by the treatment $\mathrm{T}_{1}$ (Irrigation with fresh water) and the lowest $\left(126.78 \mathrm{~kg} \mathrm{ha}^{-1} \mathrm{~mm}^{-1}\right)$ by the higher level

\section{$\multimap$ Total soluble solids}

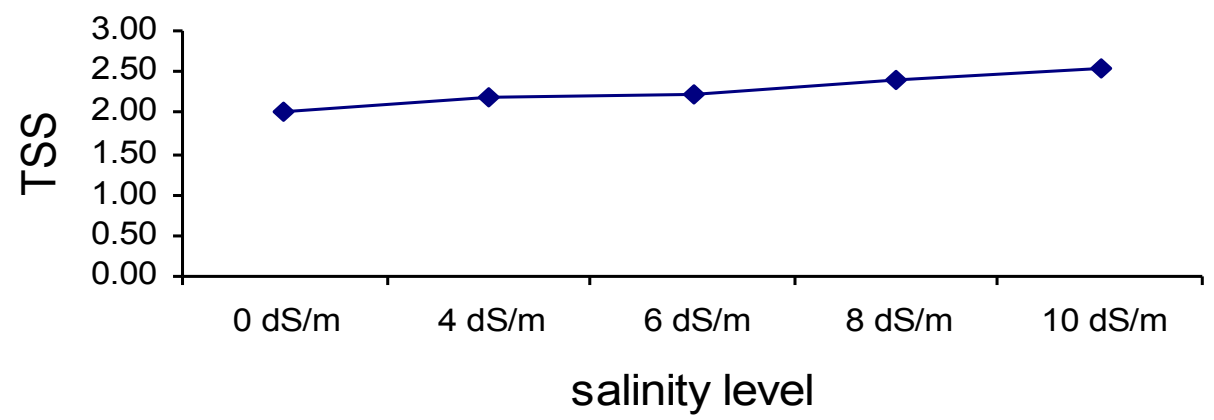

Fig. 1. Effect of saline water irrigation on total soluble solids 
Table 3. Yield and yield components of tomato as influenced by different levels of saline water irrigation

\begin{tabular}{|c|c|c|c|c|c|c|c|c|c|}
\hline & $\begin{array}{l}\text { Plant } \\
\text { height }(\mathrm{cm})\end{array}$ & $\begin{array}{l}\text { Number of } \\
\text { branches }^{-1} \\
\text { plant }^{-1}\end{array}$ & $\begin{array}{l}\text { Number of } \\
\text { fruits plant }^{-1}\end{array}$ & $\begin{array}{l}\text { Fruit } \\
\text { length } \\
\text { (cm) }\end{array}$ & $\begin{array}{l}\text { Fruit } \\
\text { diameter }(\mathbf{c m})\end{array}$ & $\begin{array}{l}\text { Fruit } \\
\text { weight }^{-1}(\mathrm{~kg}) \\
\text { plant }^{-1} \text { (kg) }\end{array}$ & $\begin{array}{l}\text { Individual } \\
\text { fruit weight } \\
\text { (g) }\end{array}$ & $\begin{array}{l}\text { Yield } \\
\left(\text { t ha }^{-1}\right)\end{array}$ & $\begin{array}{l}\text { Yield } \\
\text { decrease } \\
\text { over } \\
\text { control (\%) }\end{array}$ \\
\hline $\mathrm{T}_{1}$ & $82.67 a$ & $3.33 a$ & $23.33 a$ & $4.97 a$ & $5.82 a$ & $1.52 \mathrm{a}$ & $65.44 a$ & $36.57 a$ & -- \\
\hline $\mathrm{T}_{2}$ & $79.00 a b$ & $3.33 a$ & $22.00 a b$ & $4.81 \mathrm{a}$ & $5.62 \mathrm{ab}$ & 1.29ab & $60.05 a b$ & $34.87 a b$ & 4.65 \\
\hline $\mathrm{T}_{3}$ & 74.33abc & $3.00 a$ & $20.00 \mathrm{ab}$ & 4.63ab & $5.31 \mathrm{bc}$ & $1.17 \mathrm{bc}$ & $58.95 a b$ & $30.27 a b$ & 17.23 \\
\hline $\mathrm{T}_{4}$ & $71.33 \mathrm{bc}$ & $2.00 \mathrm{~b}$ & $17.67 b$ & $4.24 b c$ & $4.91 \mathrm{~cd}$ & $0.963 c$ & $54.33 b$ & $27.83 b c$ & 23.90 \\
\hline $\mathrm{T}_{5}$ & $66.00 \mathrm{c}$ & $2.00 \mathrm{~b}$ & $14.33 c$ & $3.91 \mathrm{c}$ & $4.62 d$ & $0.667 d$ & $46.55 c$ & $21.87 c$ & 40.20 \\
\hline CV (\%) & 4.57 & 11.57 & 7.41 & 4.27 & 2.91 & 9.53 & 4.42 & 13.37 & -- \\
\hline LSD & 9.344 & 0.8664 & 3.954 & 0.527 & 0.4155 & 0.2873 & 6.912 & 7.62 & -- \\
\hline $\begin{array}{l}\text { Level of } \\
\text { significance }\end{array}$ & $* *$ & $* *$ & $* *$ & $* *$ & $* *$ & $* *$ & $* *$ & $* *$ & -- \\
\hline
\end{tabular}

Table 4. Components of water requirement and field water use efficiency of tomato

\begin{tabular}{|c|c|c|c|c|c|c|c|}
\hline Treatments & $\begin{array}{l}\text { Number of } \\
\text { irrigation }\end{array}$ & $\begin{array}{l}\text { Amount of total } \\
\text { irrigation }(\mathrm{mm})\end{array}$ & $\begin{array}{l}\text { Effective rainfall } \\
(\mathrm{mm})\end{array}$ & $\begin{array}{l}\text { Soil moisture } \\
\text { deficit }(\mathrm{mm})\end{array}$ & $\begin{array}{l}\text { Total water } \\
\text { used }(\mathrm{mm})\end{array}$ & $\begin{array}{l}\text { Yield } \\
\left(\text { kgha }^{-1}\right)\end{array}$ & $\begin{array}{l}\text { Water use efficiency }{\left(\mathrm{kgha}^{-1}\right.}^{-1} \\
\left.\mathrm{~mm}^{-1}\right)\end{array}$ \\
\hline $\mathrm{T}_{1}$ & 3 & 120.00 & 65.0 & -12.5 & 172.5 & 36570 & 212.00 \\
\hline $\mathrm{T}_{2}$ & 3 & 120.00 & 65.0 & -12.5 & 172.5 & 34870 & 212.14 \\
\hline $\mathrm{T}_{3}$ & 3 & 120.00 & 65.0 & -12.5 & 172.5 & 30270 & 175.47 \\
\hline $\mathrm{T}_{4}$ & 3 & 120.00 & 65.0 & -12.5 & 172.5 & 27830 & 161.33 \\
\hline $\mathrm{T}_{5}$ & 3 & 120.00 & 65.0 & -12.5 & 172.5 & 21870 & 126.78 \\
\hline
\end{tabular}


of water salinity treatment $T_{5}\left(10 \mathrm{dS} \mathrm{m}^{-1}\right)$. A gradual decrease in water use efficiency was observed by increasing amount of saline water. The positive effect of studied treatments could be descending arranged as follows: $T_{1}$ (Fresh water $)>T_{2}\left(4 \mathrm{dS} \mathrm{m}^{-1}\right)>\mathrm{T}_{3}\left(6 \mathrm{dS} \mathrm{m}^{-1}\right)>\mathrm{T}_{4}(8 \mathrm{dS}$ $\left.\mathrm{m}^{-1}\right)>\mathrm{T}_{5}\left(10 \mathrm{dS} \mathrm{m}^{-1}\right)$. It is observed that saline water treatments had more impact on water use efficiency compared with fresh water treatment. In general, the increase in water salinity has decreased in the water use efficiency. Moreover, applying saline water in tomato planting not only can save valuable fresh water, but also irrigation times and depths.

\section{CONCLUSIONS}

The different levels of saline water irrigation such as fresh water, $4 \mathrm{dS} \mathrm{m}^{-1}, 6 \mathrm{dS} \mathrm{m}^{-1}, 8 \mathrm{dS} \mathrm{m}^{-1}$ and $10 \mathrm{dS} \mathrm{m}^{-1}$ exhibited significant variation in respect of fruit yield of tomato. The plants irrigated with the $T_{1}$ treatment (Irrigation with fresh water) gave the highest fruit yield plant $^{-1}$ $(1.52 \mathrm{~kg})$ whereas the lowest fruit yield plant $^{-1}$ $(0.667 \mathrm{~kg})$ was obtained from the higher level of saline water treatment $\mathrm{T}_{5}\left(10 \mathrm{dS} \mathrm{m}^{-1}\right)$. When the fruit yield was considered the effective treatment for the highest total fruit yield $\left(36.57 \mathrm{t} \mathrm{ha}^{-1}\right)$ was produced by the $\mathrm{T}_{1}$ treatment (Irrigation with fresh water) and the lowest fruit yield $(21.87 \mathrm{t}$ ha $\left.{ }^{1}\right)$ was found from the treatment $T_{5}\left(10 \mathrm{dS} \mathrm{m}^{-1}\right)$.

The effect of different salinity levels of irrigation such as fresh water, $4 \mathrm{dS} \mathrm{m}^{-1}, 6 \mathrm{dS} \mathrm{m}^{-1}, 8 \mathrm{dS}$ $\mathrm{m}^{-1}$ and $10 \mathrm{dS} \mathrm{m}^{-1}$ on total soluble solid was significantly influenced. The highest total soluble solid (2.53) was shown in $T_{5}$ treatment (10 dS $\mathrm{m}^{-1}$ ) whereas the lowest $(2.00)$ in the irrigation with fresh water treatment.

Field water use efficiency has decreased significantly with the increase in water salinity. The highest water use efficiency $(212.0 \mathrm{~kg} \mathrm{ha}$ ${ }^{1} \mathrm{~mm}^{-1}$ ) was observed in fresh water treatment whereas the lowest water use efficiency $(126.78$ $\left.\mathrm{kg} \mathrm{ha}^{-1} \mathrm{~mm}^{-1}\right)$ in the treatment $\mathrm{T}_{5}\left(10 \mathrm{dS} \mathrm{m}^{-1}\right)$.

The $T_{1}$ treatment (Irrigation with fresh water) was found to be the most effective for the optimum growth and yield of tomato (TM-153) but a little decrease in the yield of tomato in the treatment $\mathrm{T}_{2}\left(4 \mathrm{dS} \mathrm{m}^{-1}\right)$ may be used in the southern area of Bangladesh where fresh water is relatively scarce. The application of non-saline water in sensitive stage and saline water in relatively tolerant stage could minimize the reduction in yield by salinity.

\section{COMPETING INTERESTS}

Authors have declared that no competing interests exist.

\section{REFERENCES}

1. BBS. Statistical Yearbook of Agricultural Statistics of Bangladesh. Statistics Division, Ministry of Planning, Govt. of the People's Republic of Bangladesh; 2016.

2. FAO, (Food and Agricultural Organization). Food and Agriculture Organization of the United Nations Rome, Italy; 2012.

3. Ferdous Z, Datta A, Anwar M. Effects of plastic mulch and indigenous microorganism on yield and yield attributes of cauliflower and tomato in inland and coastal regions of Bangladesh. Journal of Crop Improvement; 2017.

DOI: 10.1080/15427528.2017.1293578

4. Zhai $Y$, Yang $Q$, Hou M. The effects of saline water drip irrigation on tomato yield, quality and blossom-end rot incidence --- A 3a Case Study in the South of China. PLoS ONE. 2015;10(11):e0142204.

DOI: 10.1371/journal.pone.0142204

5. Datta A, Ullah $H$, Ferdous Z. Water management in rice. In: BS Chauhan, $K$ Jabran, G Mahajan (Eds.), Rice Production Worldwide. Springer. 2017;255-277. Available:http://link.springer.com/chapter/1 0.1007/978-3-319-47516-5 11

6. Ferdous Z, Datta A, Anal AK, Anwar M, Khan MR. Development of home garden model for year round production and consumption for improving resource-poor household food security in Bangladesh. NJAS - Wageningen Journal of Life Sciences. 2016;78:103-110.

Available:http://doi.org/10.1016/j.njas.2016 .05 .006

7. Tuna $A L$, Kaya $C$, Ashraf $M$, Altunlu $H$, Yokas I, Yagmur B. The effects of calcium sulphate on growth, membrane stability and nutrient uptake of tomato plants grown under salt stress. Environmental and Experimental Botany. 2007;59:173-178.

8. Zushi K, Matsuzoe N. Utilization of correlation network analysis to identify differences in sensory attributes and organoleptic compositions of tomato cultivars grown under salt stress. Scientia Horticulturae. 2011;129:18-26

9. Hou M, Shao X, Zhai Y. Effects of different regulatory methods on improvement of greenhouse saline soils, tomato quality, 
and yield. Scientific World Journal. 2014; Article ID 953675.

10. Datta A, Shrestha S, Ferdous Z, Win CC. Strategies for enhancing phosphorus efficiency in crop croduction systems. In Nutrient Use Efficiency: From Basics to Advances, edited by A. Rakshit, H. B. Singh and A. Sen. Springer. 2015;59-71. ISBN: 978-81-322-2169-2

Available:http://link.springer.com/chapter/1 $\underline{0.1007 / 978-81-322-2169-25}$

(Accessed August 7, 2016)

11. Bustan A, Cohen S, Sagi M, Golan R, DeMalach Y, Pasternak D. The-use-ofsaline-and-brackish-water-for-irrigationImplications-for-the-management-ofirrigation, drainage and crops. Proceedings of the International Workshop at the Tenth ICID Afro Asian Regional Conference on Irrigation and Drainage, Denpasas, Bali, Indonesia, 19-26-July. 1998;193-200.

12. Minhas PS. Saline water management for irrigation in India. Agricultural Water Management.1996;35:1-24.

13. Del Amor FM, Martinez V, Cerda A. Salt tolerance of tomato plants as affected by stage of plant development. Hortscience. 2001;36:1260-1263.

14. Cuartero J, Gomez-Guillamon ML, Romero-Aranda R, Reina-Sanchez A, Caro M, Perez-Alfocea F, Bolarin MC. Sustainable strategies for irrigation in salt prone-Mediterranean-Region: A system approach. Proceedings of an International-
Workshop, Cairo,-Egypt, 8-10-December. 2003;46-58.

15. Boari F, Donadio A, Pace B, Schiattone MI, Cantore V. Kaolin improves salinity tolerance, water use efficiency and quality of tomato. Agricultural Water Management. 2016;167:29-37.

16. Brady NC, Weil RR. The nature and properties of soils. $13^{\text {th }}$ ed. Prentice Hall, Upper Saddle River; 2002.

17. Leone AP, Menenti M, Sorrentino G. Reflectance spectroscopy to study crop response to soil salinity. Italian Journal of Agronomy. 2000;4(2):75-85.

18. Terre-González Alejandrodela, Albacete A, Sánchez E, naBlasco B, Ruiz JM. Comparative study of the toxic effect of salinity in different genotypes of tomato plants: Carboxylates metabolism. Scientia Horticulturae. 2017;217:173-178.

19. FRG. Fertilizer recommendation guide, Bangladesh Agricultural Research Council, BARC, Farmgate, Dhaka. 2012;1215.

20. Katerji N, van Hoorn JW, Hamdy A, Mastrorilli M. Response of tomatoes, a crop of indeterminate growth, to soil salinity. Agricultural Water Management. 1998;38:59-68.

21. Elamin EA, Al-Wehaibi NS. Alternate use of good and saline irrigation water $(1: 1)$ on the performance of tomato cultivar. Journal of Plant Nutrition. 2005; 28(6):1061-1072.

(c) 2017 Ahmed et al.; This is an Open Access article distributed under the terms of the Creative Commons Attribution License (http://creativecommons.org/licenses/by/4.0), which permits unrestricted use, distribution, and reproduction in any medium, provided the original work is properly cited.

Peer-review history:

The peer review history for this paper can be accessed here: http://sciencedomain.org/review-history/19391 